\title{
Combined effects of temperature and salinity on growth rates of germlings of three Fucus species from Iceland, Helgoland and the North Adriatic Sea
}

\author{
I. M. Munda \\ Biological Institute, Slovene Academy of Science; Ljubljana, Jugoslavia \\ and \\ Biologische Anstalt Helgoland(Meeresstation); Helgoland, \\ Federal Republic of Germany
}

\begin{abstract}
The growth rate of germlings of three Fucus species (F. distichus. subsp. edentatus from Iceland, $F$. vesiculosus from Helgoland, North Sea, and $F$. virsoides from the North Adriatic Sea) has been investigated under different temperature and salinity conditions. The highest growth rate and the maximum elongation factor were found at $9^{\circ} \mathrm{C}$ for $F$. distichus; in the other two species growth increased with increasing temperature. Growth decreases with dilution in the three species under consideration. A tather low tolerance to dilution was observed in $F$, vesiculosus germlings. In view of the overall distribution of the latter species the opposite was expected. It seems likely, however, that susceptible strains have developed at Helgoland, where salinity rarely drops below $30 \%$.
\end{abstract}

\section{INTRODUCTION}

Species of the genus Fucus are generally cold water plants; their geographical distribution is widely controlled by temperature (Setchell, 1920; Hutchins, 1947; Scagel, 1963; Humm, 1969; Gessner, 1970). Some fucoids are able to extend into estuaries and salinity is a further deciding factor for their local distribution (e.g. Jorde \& Klavestad, 1963; Munda, 1964, 1967, 1972a). The growth performances of three different Fucus species, originating from various geographical latitudes, were investigated under different temperature and salinity conditions in culture: $F$. distichus subsp. edentatus from Iceland, $F$. vesiculosus from Helgoland and $F$. virsoides from the North Adriatic Sea. Interest arose in how much the growth of germlings raised in the laboratory is influenced by temperature and whether inhibition by means of dilution of the media is also temperature controlled.

\section{MATERIAL AND METHODS}

Fertile material of Fucus distichus L. emend Powell subsp. edentatus (de la Pyl.) Powell was obtained in March 1975 from Hafnir, southern Iceland and fertile material 
of $F$. virsoides (Don.) J. Ag. at the same time from Rovigno, Jugoslavia. F. vesiculosus L. plants were collected in the rocky eulittoral zone of Helgoland.

Receptacula of the two monoecious species were rinsed and suspended over 31 vessels filled with filtered sea water. The zygotes were caught on plastic plates $(3 \times 5 \mathrm{~cm} \mathrm{PVC})$ where they were allowed to settle. The plants were transferred to Petri dishes with Provasoli enriched seawater at $12^{\circ} \mathrm{C}$. Later small plants attached to the plates were transferred to a seawater shower. Unattached plants were kept in Petri dishes in Provasoli solution. All germlings were kept under constant illumination of 1500 to 2000 lux. Germlings of $F$. vesiculosus were obtained by artificial fertilization and were kept in Petri dishes under the same conditions.

In December the small plants were transferred into solutions of different salinities, prepared from filtered seawater diluted with distilled water. Cultures were kept at $3^{\circ} \mathrm{C}, 6^{\circ} \mathrm{C}, 9^{\circ} \mathrm{C}, 12^{\circ} \mathrm{C}$ und $15^{\circ} \mathrm{C}$ at constant illumination of 1500 to $2000 \mathrm{lux}$. Control samples were kept in a seawater shower and in Petri dishes in Provasoli solution. Further controls were kept in media of different salinities in aerated 31 vessels for $F$. distichus subsp. edentatus and $F$. vesiculosus. The size of the plants was measured initially in December 1975 and next in February and May 1976. Each sample contained 10 to 20 plants for $F$. distichus and $F$. vesiculosus and about 50 germlings for $F$. virsoides. The elongation factor was determined by dividing the plants 's length after six months by the initial length. The average initial length was $0.4 \mathrm{~cm}$ for $F$. distichus, $0.2 \mathrm{~cm}$ for $F$. vesiculosus, and $670 \mu \mathrm{m}$ for $F$. virsoides.

\section{RESULTS}

In Fucus distichus subsp. edentatus there is a clear trend of decreasing growth with dilution of the media (Fig. 1). Growth rate increases up to $9^{\circ} \mathrm{C}$ which is optimal. In the extremely diluted medium of $2.7 \% \mathrm{~S}$ a decline in growth with increasing temperature became evident. The growth rate seems highly inhibited at this concentration. Only about $20 \%$ of plants kept at this concentration at $15^{\circ} \mathrm{C}$ were able to survive.

On the other hand at $5.2 \% \mathrm{~S}$, all plants survived at this temperature and a peak in growth intensity was indicated at $9^{\circ} \mathrm{C}$ as in the rest of the samples. The elongation factor (Fig. 1) was maximal for plants kept in seawater at $9^{\circ} \mathrm{C}$. For experimental material kept in the medium of $15.4 \% 0 \mathrm{~S}$ the peak was indicated at the same temperature, while it was less marked for plants kept at $5.2 \%$. A decline in the elongation factor was found at $6^{\circ} \mathrm{C}$ in some of the salinity series.

Control plants kept in the seawater shower did not differ essentially in sizes from those kept for control in stagnant seawater. They were heavily epiphytized by diatoms and Ectocarpus sp. and unsuitable for comparison. Control plants kept at different salinities in aerated vessels exhibited, on the other hand, an even more pronounced gradation in growth intensity with decreasing salinities than those kept in stagnant media. These controls were kept at $12^{\circ} \mathrm{C}$ under constant illumination (Fig. 6). The size of the plants kept at high and medium salinities exceeded that of the plants kept at the same concentrations in stagnant media. 


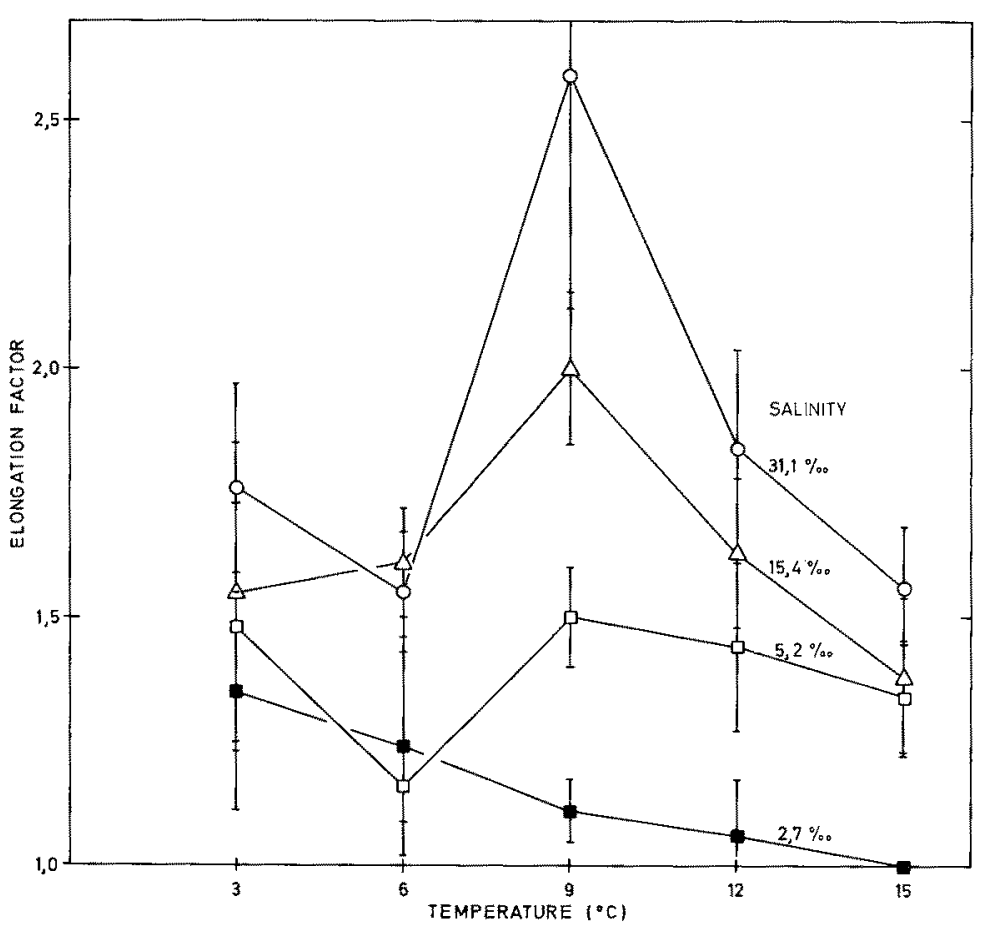

Fig. 1: Elongation factor for Fucus distichus subsp. edentatus plants cultivated at different temperatures and salinities for six months. Vertical lines at each point indicate standard deviation. $(\mathrm{n}=10$ to 20$)$

In $F$. vesiculosus germlings the salinity-induced reduction of growth activity seems even more pronounced than in $F$. distichus. The opposite was expected, since under field conditions $F$. vesiculosus is able to extend farther into estuaries than $F$. distichus. A rather pronounced decrease in growth is evident in plants kept at $15.4 \%$ S. Only negligible growth activity was detected at $5.2 \% \mathrm{~S}$ and none at $2.7 \% \mathrm{~S}$. The temperature dependence of growth activity is different than in $F$. distichus. The growth rate increases from lower towards higher temperatures. The maximum growth occurred at $15^{\circ} \mathrm{C}$. The elongation factor (Fig. 2) for plants kept in seawater was maximal at $12^{\circ} \mathrm{C}$, while for plants kept at $15.4 \% \mathrm{~S}$ the maximum shifted to $15^{\circ} \mathrm{C}$.

The third experimental fucoid species, $F$. virsoides had the smallest germlings (average size $670 \mu \mathrm{m}$ ) with long rhizoids and hairs. Ramification appeared in only a small percentage of germlings. The trend of increase in growth with increasing temperature is strongly expressed in this species. The optimum temperature for growth is probably not yet reached at $15^{\circ} \mathrm{C}$. The increase in growth rate from 3 to $6^{\circ} \mathrm{C}$ is negligible, but is marked between 6 and $9^{\circ} \mathrm{C}$ and highest at $15^{\circ} \mathrm{C}$. A rather clear trend of decreased growth rate with dilution is evident also in this fucoid. Plants kept at $5.4 \% 0 \mathrm{~S}$ still exhibited some growth at temperatures above $9^{\circ} \mathrm{C}$, while those kept at $2.7 \%$ did not survive even 2 to 3 months. 


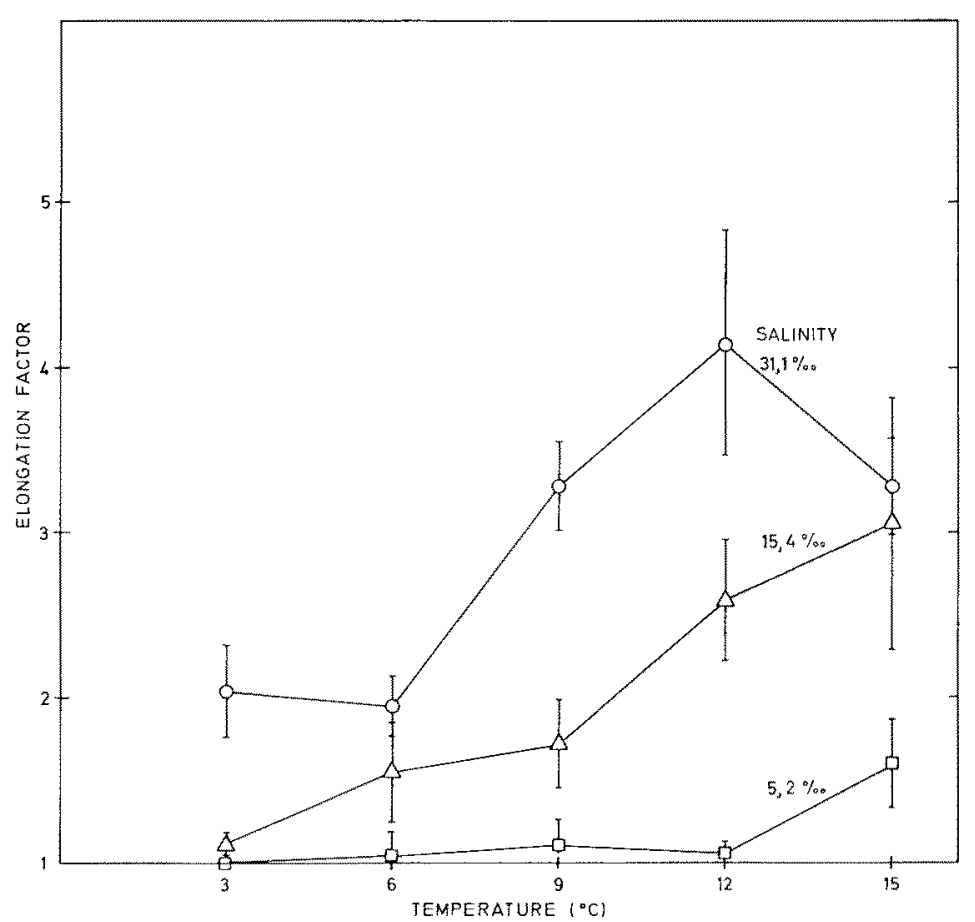

Fig. 2: Elongation factor for Fucus vesiculosus plants cultivated at different temperatures and salinities for six months. Vertical lines at each point indicate standard deviation ( $\mathrm{n}=10$ to 20 )

\section{DISCUSSION AND CONCLUSIONS}

The results indicate a clear relationship between the optimal temperature for growth and the geographical distribution of the fucoid species studied, which has also been found in Halidrys siliquosa (Moss \& Sheader, 1973) and Ascoplyyllum nodostm (Sheader \& Moos, 1975).

Fucus distichus subsp. edentatus is one of the most common low-level fucoids in Iceland. It has, in general, a northerly distribution in the Atlantic Sea. In Iceland, it forms belts below $F$. vesiculosus and A. nodosum and is adapted to rather vigorous surf conditions. Field observations in Iceland revealed that this subspecies of $F$. distichus extends into vicinity of river outlets, where the salinity rise is rather abrupt. A tolerance towards salinity fluctuations is thus indicated. In the South of Iceland, around the Reykjanes Peninsula, from where the experimental material was obtained, yearly temperature means range between 7.5 and $7.8^{\circ} \mathrm{C}$ (Stefánsson, 1969). Temperature maxima in July and August range between 10.0 and $11.2^{\circ} \mathrm{C}$ and winter minima in January and February between 5.2 and $5.8^{\circ} \mathrm{C}$ according to the same author (Fig. 4). During my own observations around Hafnir, Reykjanes Peninsula, in August 1972, surface water temperatures of $8.0^{\circ} \mathrm{C}$ in exposed and $12.9^{\circ} \mathrm{C}$ in sheltered sites were found (Munda, 1976). In the present experiment, maximum enlargement occurred at 


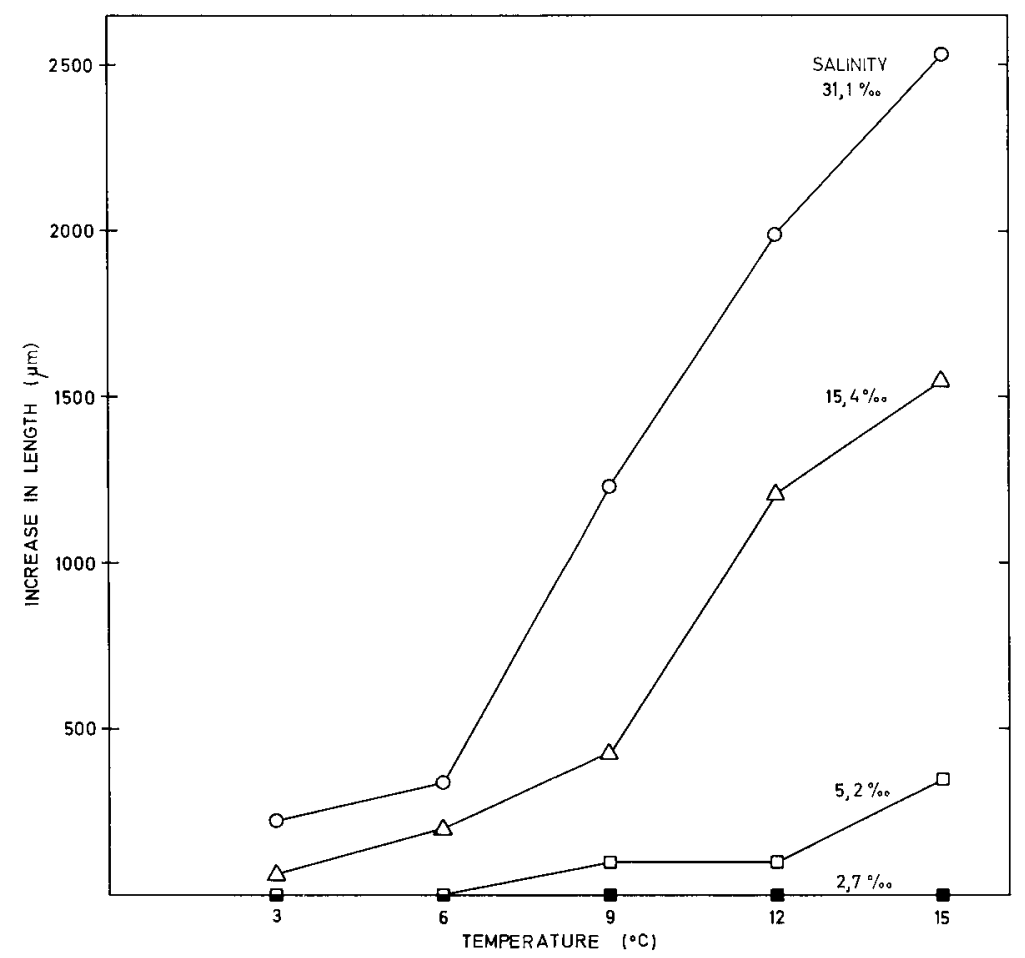

Fig. 3: Increase in length for Fucus virsoides plants, cultivated at different temperatures and salinities for six months

$9^{\circ} \mathrm{C}$ which corresponds to the average summer temperature in the original habitat in southern Iceland (Fig. 4). $12^{\circ} \mathrm{C}$, however, corresponds to exceptionally high summer temperatures in the South of Iceland, while $15^{\circ} \mathrm{C}$ surpasses the temperature conditions in the natural habitats of $F$. distichus. This temperature level seems to cause the maximum inhibition of growth. A genetically inherited temperature response is thus assumed to be present in $F$. distichus strains from Iceland. McLachlan (1974), studying the effect of light and temperature on the growth and development of $F$. distichus embryos from Halifax, found a rapid rate of growth and normal development at $15^{\circ} \mathrm{C}$ but a delayed growth and indicated necrosis at $20^{\circ} \mathrm{C}$.

Considering the growth of plants in media of different salinities, a rather pronounced tolerance towards dilution is indicated, although linked to a decrease in growth rate; reduction in body size being a rather common phenomenon in estuarine areas (Gessner \& Schramm, 1971). Growth was poorest at $2.7 \% \mathrm{~S}$ and this negative effect was even more pronounced at higher temperatures. Salinity induced differences in growth were most prominent in aerated cultures. This corresponds more or less to the distribution pattern found for $F$. distichus during present studies in Iceland. Salinities of the original habitat of Fucus distichus subsp. edentatus range between $32.3 \%$ and $34.9 \% \mathrm{~S}$ for the Reykjanes Peninsula (Stefánsson et al., 1961); it was $17.5 \%$ to $26.7 \%$ S for the surroundings of Hafnir and $33.1 \%$ to $34.4 \%$ oo $\mathrm{S}$ for Gardskagí at 


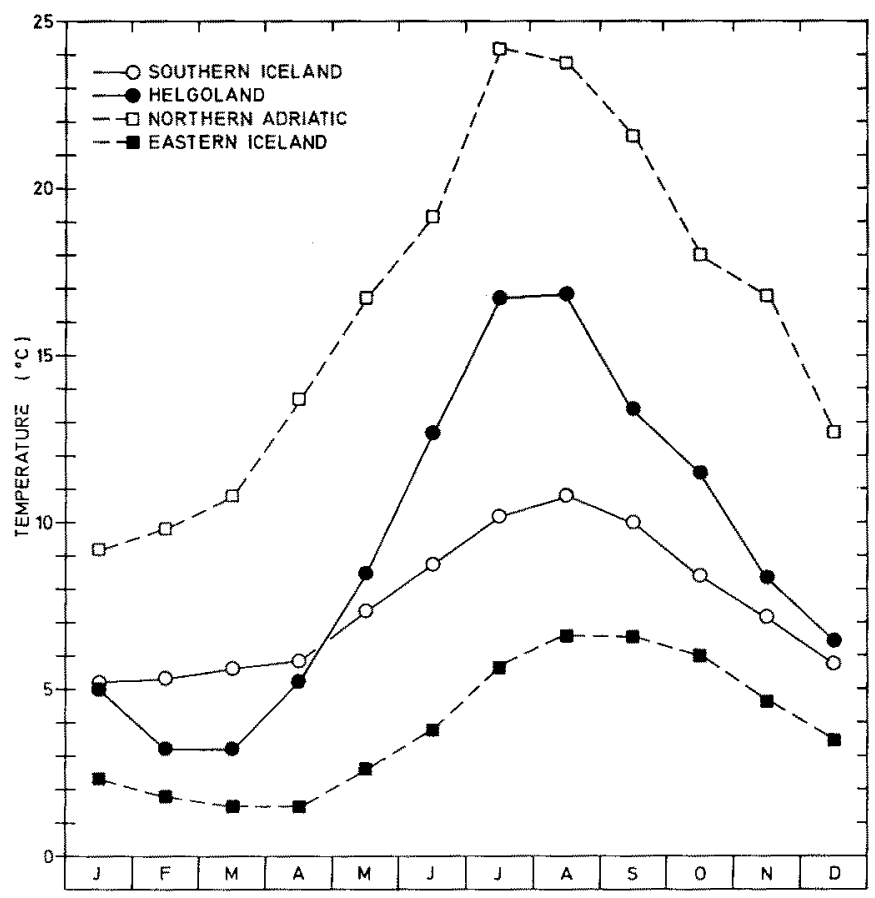

Fig. 4: Yearly range of surface water temperatures for southern Iceland, eastern Iceland (Stefánsson, 1969), Helgoland (Treutner, unpublished) and the northern Adriatic (Munda, unpublished)

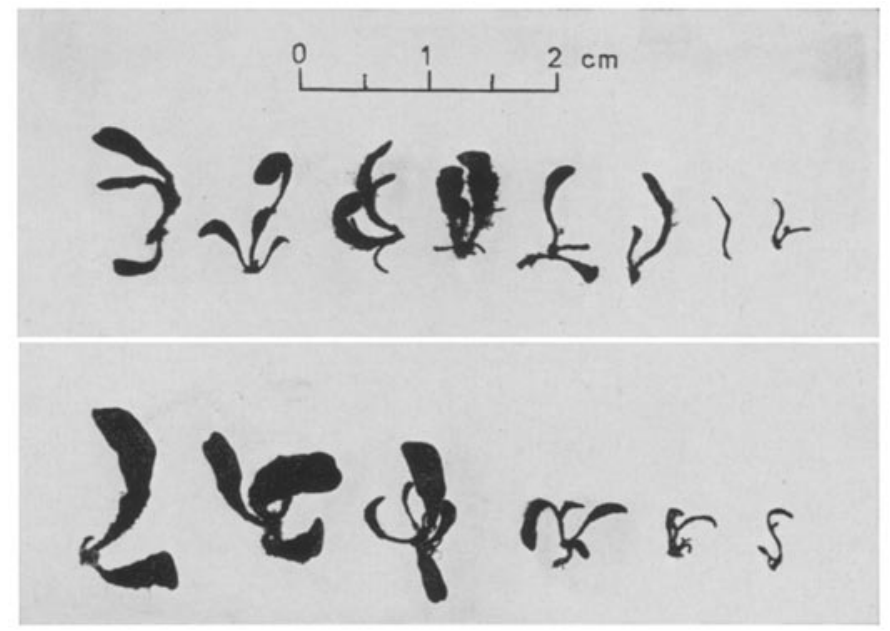

Fig. 5: Initial material of Fucus distichus subsp. edentatus germlings 


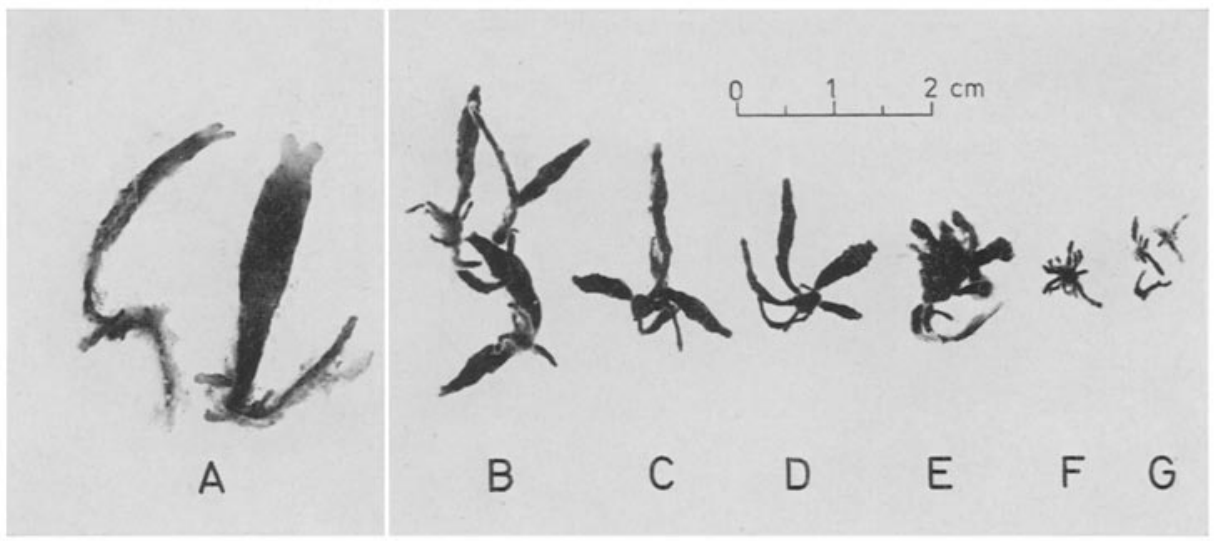

Fig. 6: Fucus distichus subsp. edentatus plants, kept for six months in aerated media of different salinities (average size of the initial material $0.4 \mathrm{~cm}$ ) (A) $31.1 \%$; (B) $26.0 \%$; (C) $20.9 \% ;$ (D) $15.4 \%$; (E) $10.7 \%$; (F) $5.2 \%$; (G) $2.7 \%$

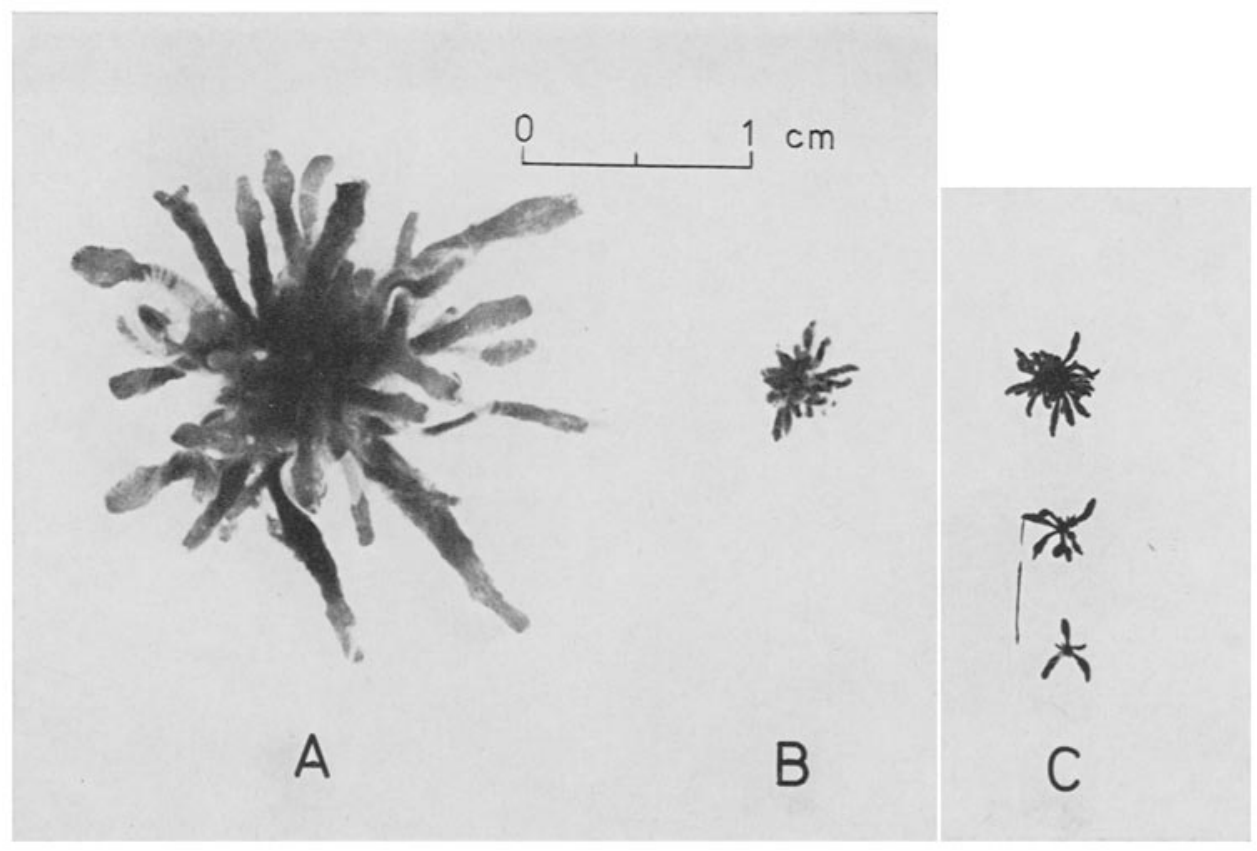

Fig. 7: Fucus vesiculosus plants: (A) plants kept for six months in aerated seawater of $31.1 \%$ salinity; (B) plants kept for six months in aerated water of $5.2 \%$ salinity; (C) initial material 
Reykjanes according to measurements for the surface water in August 1975 (Munda, unpublished).

The second monoecious fucoid, $F$, virsoides, is ecologically different in many aspects. In the Mediterranean Sea it is subject to a minimal tidal amplitude, to elevated temperatures (Fig. 4) and salinities as well as to a rather uniform day length throughout the year. The small germlings of this endemic fucoid, which seems to be closely related to $F$. spiralis, exhibit increased growth with increasing water temperatures. In its original habitat, near Rovigno in the northern Adriatic Sea, the minimum winter temperatures are encountered in February and range from 9 to $10^{\circ} \mathrm{C}$ (Munda, 1972b). Thus this species is never subjected to temperatures below $8^{\circ} \mathrm{C}$. The decreased growth rate at 3 and $6^{\circ} \mathrm{C}$ and the increase in growth rate at higher temperatures correlates well with conditions in the plant 's original habitat. Temperatures of 12 and $15^{\circ} \mathrm{C}$ correspond to late spring temperatures from April to May, when the growth in the natural habitat is rather vigorous, according to my own observations in the Adriatic. Summer temperatures, on the other hand, range over $20^{\circ} \mathrm{C}$.

The salinity in the Mediterranean Sea is considerably higher than in the Atlantic, ranging between 36.8 and $37.9 \% \mathrm{~S}$ in the surroundings of Rovigno (Munda, 1972b). $F$. virsoides thrives in lowered salinities around submarine freshwater springs, as e.g. at 8 to $12 \% 0 \mathrm{~S}$ (Munda, 1972a). In lowered salinities, a reduction in body size was observed in this fucoid (Munda, 1972a). F. virsoides still exhibited some growth activity at $10 \%$ S but a negligible activity at $5 \%$, which seems the lowest range of its tolerance. It is, however, not able to survive at $2 \% \mathrm{~S}$.

The growth optimum of $F$. vesiculosus from Helgoland at $15^{\circ} \mathrm{C}$ is in accordance with its local thermal regime (Fig. 4). At high salinities the growth rate of $F$. vesiculosus is greater than that of $F$. distichus subsp. edentatus at its optimum of $9^{\circ} \mathrm{C}$. Inverse conditions were found at $15 \% \mathrm{~S}$, which suppresses the growth rate of $F$. vesiculosts to a greater degrce than that of $F$. disticlsus. These conditions are even more pronounced in strongly diluted media. Regarding its distribution pattern, however, a higher tolerance towards dilution of the media would be expected in $F$. vesiculosus than in $F$. disticbus.

Previous studies on the distribution and salinity tolerance of $F$. vesiculosus in estuaries (Munda, 1964, 1967) along with recent, yet unpublished observations of its overall distribution in Iceland, indicate a rather high tolerance towards lowered salinity in this species, surpassing greatly that of $F$. distichus $I_{n}$ inner fjord areas in Iccland, $F$. vesiculosus (along with $F$. ceranoides) was found in estuaries down to $2 \% \mathrm{~S}$. A tendency towards dwarf growth forms is indicated in this species from Finland ( $f$. subcostata) from salinities 5 to $6 \%$ (Gessner \& Schramm, 1971).

It is finally noteworthy that the $F$. vesiculosus growth forms found at Helgoland differ essentially from those observed along the coast of the north European mainland and Iceland, and it seems probable that $F$, vesiculosis at Heigoland is more sensitive to lowered salinity than $F$. vesiculosus elsewhere.

Acknowledgements. Fucus distichus subsp. edentatus was provided by mag. sci E. Siggeirsson, Reykjavík, and F. virsoides by Dr. N. Zavodnik, Centre for Marine Research, Rovigno. The author feels greatly indebted to both. Further thanks are due to Dr. K. Lüning, Biologische Anstalt Helgoland, for his help and suggestions, to Dr. J. W. Markham for reading 
the manuscript, to Mr. H. P. Sahling for photographic help and to Mr. M. Amelung for drawing the figures. The work was carried out while the author was supported by a research fellowship from the Alexander von Humboldt Foundation.

\section{LITERATURE CITED}

Gessner, F., 1970. Temperature-Plants. In: Marine ecology. Ed. by O. Kinne. Wiley-Interscience, London, 1 (1), 363-406.

- \& Schramm, W., 1971. Salinity-Plants. In: Marine ecology. Ed. by O. Kinne. WileyInterscience, London, 1 (2), 705-820.

Humm, H. J, 1969. Distribution of marine algae along the Atlantic coast of North America. Phycologia 7, 43-53.

Hutchins, I. W., 1947. The basis of temperature zonation in the geographical distribution. Ecol. Monogr. 17, 325-335.

Jorde, I. \& Klavestad, N., 1963. The natural history of the Hardangerfjord. 4. The benthonic algal vegetation. Sarsia 9, 1-99.

McLachlan, J., 1974. Effects of temperature and light on the growth and development of embryos of Fucus edentatus and F, distichus subsp. distichus. Can. J. Bot. 52, 943-951.

Moss, B. \& Sheader, A., 1973. The effect of light and temperature upon the germination and growth of Halidrys siliquosa (L.) Lyngb. (Phaeophyceae, Fucales). Phycologia 12, 63-68.

Munda, I., 1964. Observations on variations in form and chemical composition of Fucus ceranoides L. Nova Hedwigia 8, 405-414.

-- 1967. Der Einfluß des Salzgehaltes auf die chemische Zusammensetzung, Wachstum und Fruktifizierung von einigen Fucaceen. Nova Hedwigia 13, 471-508.

- 1972a. Seasonal and ecologically conditioned variations in the Fucus virsoides association from the Istrian coast (northern Adriatic). Razprave, SAZU. (Cl. 4.) 15 (1), 1-33.

- 1972b. The production of biomass in the settlements of benthic algae from the northern Adriatic. Botanica mar. 15, 218-244.

- 1976. Some aspects of the benthic algal vegetation of the South Icelandic coastal area. Bull. Res. Inst. Nedri Âs, Hveragerdi, Iceland 25, 1-69.

Scagel, R. F., 1963. Distribution of attached marine algae in relation to oceanographic conditions in the northern Pacific. Spec. Publs. Can. 5, 37-50.

Setchell, W. A., 1920. The temperature interval in geographical distribution of marine algae. Science N.Y. 52, 187-190.

Sheader, A. \& Moss, B., 1975. Effects of light and temperature on germination and growth of Ascophyllum nodostum (L.) Le Jol. Estuar, coast. mar. Sci. 3, 125-132.

Stefánsson, U., 1969. Sjávarhíti á siglingaleiđ umhverfis İsland. Hafísinn. Almenna bokafélagiđ, Reykjavík, 131-149.

- Lindal, B., Jakobsson, J. \& Jónsson, I., 1961. The salinity at the shores of southwest Iceland. Rit Fiskideild. 2, 1-20.

Author's adress: Dr. Ivka M. Munda

Biological Institute

Slovene Academy of Science

Ljubljana

Jugoslavia 